\title{
Pengaruh Model Brain Based Learning dan Problem Based Learning terhadap Keterampilan Berpikir Kompleks Matematis ditinjau dari Kreativitas Siswa Sekolah Dasar di Kabupaten Bima
}

\author{
Adi Apriadi Adiansha ${ }^{1, *}$, Khairul Sani ${ }^{1}$ \\ ${ }^{1}$ STKIP Taman Siswa Bima \\ *adiapriadiadiansyah@gmail.com
}

Abstrak: Fakta yang terjadi terhadap kualitas pendidikan sekolah dasar di Kabupaten Bima mengalami penurunan hal ini sesuai dengan data PISA dan TIMSS. Tujuan penelitian untuk mengethui 1) Perbedaan keterampilan berpikir kompleks matematis yang diberi perlakukan dengan Model Brain Based Learning dengan Problem Based Learning pada siswa Sekolah Dasar; 2) interaksi antara Model Brain Based Learning dan Problem Based Learning terhadap keterampilan berpikir kompleks matematis yang ditinjau dari kreativitas siswa Sekolah Dasar; 3) perbedaan keterampilan berpikir kompleks matematis pada siswa yang diberi perlakukan Model Brain Based Learning dan Problem Based Learning yang memiliki kreativitas tinggi; 4) perbedaan keterampilan berpikir kompleks matematis pada siswa yang diberi perlakukan Model Brain Based Learning dan Problem Based Learning yang memiliki kreativitas rendah. Metode penelitian ini merupakan penelitian eksperimen yang didesain dengan treatment by level 2x2. Subjek penelitian di SDN Nggembe dan SDN Rada di Kabupaten Bima. Hasil penelitian menujukkan bahwa untuk hipotesis pertama mengatakan bahwa terdapat perbedaan keterampilan berpikir kompleks matematis pada siswa yang diberi model Brain Based Learning dengan siswa yang diberi model Problem Based Learning. Hipotess kedua mengatakan adanya interaksi antara pembelajaran yang diberikan dengan tingkat kreativitas siswa terhadap keterampilan berpikir kompleks matematis siswa. Hipotesis ketiga mengatakan bahwa adanya perbedaan keterampilan berpikir kompleks matematis antara siswa yang diberikan model Brain Based Learning dengan yang diberikan model Problem Based Learning pada kelompok siswa dengan kreativitas tinggi. Hipotesis keempat perbedaan keterampilan berpikir kompleks matematis antara siswa yang diberikan model Brain Based Learning dengan yang diberikan model Problem Based Learning pada kelompok siswa dengan kreativitas rendah. Penelitian ini sangat direkomendasikan keberlanjutan dalam terus melakukan penelitian karena penting untuk

Kata Kunci: Brain Based Learning, Problem Based Learning, Keterampilan Berpikir Kompleks Matematis, Kreativitas Siswa

\section{Pendahuluan}

Fakta yang terjadi terhadap kualitas pendidikan di Indonesia mengalami penurunan, hal tersebut berdasarkan hasil survei PISA tahun 2018 bahwa Indonesia berada errebnmpada peringkat 72 dari 78 negara peserta dengan skor rata-rata 379 untuk kategori di bidang matematika (OECD, 2019; Schleicher, 2019). Kemudian, hasil TIMSS menunjukkan hasil prestasi siswa di bidang matematika mendapat peringkat 46 dari 51 negara dengan skor 397. Sehingga membuktikan bahwa data kualitas pendidikan di Indonesia masih jauh dari harapan yang diinginkan.

Keterampilan berpikir kompleks pada siswa mampu memberikan dampak dalam meningkatkan kualitas pendidikan di Indonesia terutama di jenjang Sekola Dasar, hal tersebut dapat dilihat menunjukkan bahwa keadaan siswa hasru dapat melihat secara utuh dalam menyelesaikan permasalah secara menyeluruh dan utuh a (Dewi \& Riandi, 2016; Sunardjo et al., 2016). Sebagai salah satu contoh pengaplikasian dalam peningkatan keterampilan berpikir kompleks pada siswa dapa dilihat pada gambar 1 . 


\begin{tabular}{|l||c||}
\hline \hline Berpikir Tradisional & Berpikir Kompleks \\
pada Siswa & pada Siswa \\
$4+4=\mathbf{8}$ & $\mathbf{8}=4+4$ \\
& $2+6$ \\
& $12-4$ \\
& $4 \times 2$ \\
& $24: 3$ \\
& $\sqrt{64}$ \\
\hline
\end{tabular}

Gambar 1. Perbedaan Keterampilan Berpikir Siswa

Realita yang terjadi dilapangan pada sekolah dasar yang ada di Kecamatan Bolo Kabupaten Bima Nusa Tenggara Barat memiliki keterampilan berpkir berpikir kompleks matematis masih belum maksimal. Hasil pengamatan awal seperti pada gambar 1 memiliki keterampilan dalam berpikir sangat berbeda. Mengapa keterampilan berpikir kompleks perlu dibangun pada setiap siswa?, karena Indikator keterampilan berpikir kompleks yaitu keterampilan siswa masih belum maksimal dalam menyelesaikan permasalahan, baik dalam pengambilan keputusan secara berpikir kritis maupun berpikir kreatif dalam (Dewi \& Riandi, 2016). Sehingga dalam penelitian ini mengarahkan siswa untuk mampu berpikir kompleks secara matematis yang mengharusnkan untuk pemahaman terhadap pemecahan masalah matematika baik diselesaikan dengan cara berpikir kritis dan berpikir kreatif dalam sebuah permasalahan.

Alternatif dalam menyelesaikan permasalahan terhadap peningkatan keterampilan berpikir kompleks matematis dapat dilakukan dengan menggunakan dua model pembelajaran yang sama-sama dalam penyelesaian permasalahan secara aktif pada siswa yaitu model Brain Based Learning dan model Problem Based Learning. Hasil penelitian sebelumnya mengatakan bahwa model Brain Based Learning merupakan salah satu pembelajaran yang memaksimalkan fungsi otak yang dimiliki siswa yang dilakukan secara ilmiah dalam proses pembelajaran (Adiansha et al., 2018; Adiansha \& Sumantri, 2017; Permana \& Adiansha, 2019; Yasar, 2017). Tahapan Model Brain Based Learning yaitu 1) Pra-pemaparan, 2) Persiapan, 3) Inisiasi dan akuisisi, 4) Elaborasi, 5) Inkubasi dan memasukkan memori, 6) Verifikasi dan pengecekan keyakinan, dan 7) Perayaan dan integrasi. Sedangkan, Model Problem Based Learning merupakan model pembelajaran yang diselesaikan dengan cara menyelesaikan permasalaha dalam proses pembelajaran melalui cara berpikir kritis dalam memperoleh pengetahuan (Maskur et al., 2020). Tahapan Model Problem Based Learning yaitu 1) Permasalahan awal, 2) Pengelompokkan siswa, 3) Pengarah siswa baik dilakukan secara individu maupun kelompok, 4) Pengembangan terhadap hasil pembelajaran, dan 5) Menganalisis dan mengevaluasi pembelajaran.

Dalam melihat nilai keterampilan berpikir kompleks matematis pada siswa dilakukan dengan menggunakan instrumen tes kreativitas siswa terlebih dahulu dengan membuat instrumen penelitian melalui model gambar sehingga dari bagian model gambar tersebut akan dilakukan dengan memberikan indikator penilaian yaitu lancar, luwes, orisinal, dan elaborasi. Dari model gambar tersebut dibuat menjadi gambar yang memiliki nama sesuai dengan hasil kreativitas siswa, model gambar tersebut dapat dilihat pada gambar 2.
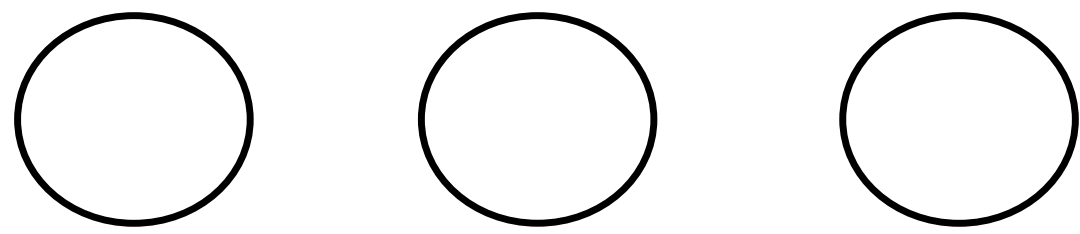

Gambar 2. Tes untuk mengukur Kreativitas Siswa

Hasil penelitian dilakukan oleh Adiansha mengemukakan bahwa kreativitas merupakan kemampuan yang dimiliki siswa sehingga bisa melahirkan ide dan gagasan yang terbaru yang mencerminkan kelancaran, keluwesan dan orisinalitas berpikir serta kemampuan elaborasi (Adiansha et al., 2018, 2020; Adiansha \& Sumantri, 2017). Lebih lanjut peneliti lain mengatakan bahwa kreativitas merupakan membantu siswa dalam mengembangkan bakat yang dimilikinya untuk meraih prestasi dalam pembelajaran (Haynes, 2020; Pllana, 2019).

Penelitian ini urgent dilakukan karena melihat dari beberapa penelitian sebelumnya bahwa menyatakan bahwa model Brain Based Learning memiliki pengaruh positif yang signifikan terhadap kemampuan komunikasi matematis yang ditinjau dari kreativitas siswa (Adiansha et al., 2018). Selain itu, penelitian yang dilakukan oleh (Anita \& Mumpuniart, 2018) menyampaikan bahwa odel Problem Based Learning mampu memberikan pengaruh 
positif terhadap kemampuan berpikir kreatif pada siswa. Sehingga dengan beberapa penelitian yang relevan di atas, menunjukkan terjadi perbedaan dengan penelitian yang dilakukan sekarang ini yaitu pada variabel penelitian dengan membandingkan sama-sama model pembelajaran yang memiliki keaktifan pada siswa, situasi dan keadaan pada penelitian juga memiliki perbedaan.

Simpulan permasalahan menjadikan sebuah judul dalam penelitian yang mengikat terhadap permaslahan diatas, adapun judul penelitian ini yaitu Pengaruh Model Brain Based Learning dan Problem Based Learning terhadap Keterampilan Berpikir Kompleks Matematis yang Ditinjau dari Kreativitas Siswa. Tujuan permasalah penelitian ini untuk mengetahui tentang 1) perbedaan keterampilan berpikir kompleks matematis yang diberi perlakukan dengan Model Brain Based Learning dan Problem Based Learning pada siswa Sekolah Dasar; 2) Interaksi antara Model Brain Based Learning dan Problem Based Learning terhadap keterampilan berpikir kompleks matematis yang ditinjau dari kreativitas siswa Sekolah Dasar; 3) Perbedaan keterampilan berpikir kompleks matematis pada siswa yang diberi perlakukan Model Brain Based Learning dan Problem Based Learning yang memiliki kreativitas tinggi; 4) Perbedaan keterampilan berpikir kompleks matematis pada siswa yang diberi perlakukan Model Brain Based Learning dan Problem Based Learning yang memiliki kreativitas rendah.

\section{Metode}

Pelaksanaan Penelitian ini tetap akan mengikuti ketentuan dan aturan di Masa Pandemi Covid-19. Metode yang digunakan dalam penelitian ini yaitu metode penelitian eksperimen dengan treatment by level $2 \times 2$. Dimana variabel bebas yaitu Model PBL dan Model PBL, variabel terikat yaitu keterampilan berpikir kompleks matematis, dan variabel atribut yaitu kreativitas siswa. Desain penelitian dapat dilihat pada tabel 1.

Tabel 1. Desain Penelitian

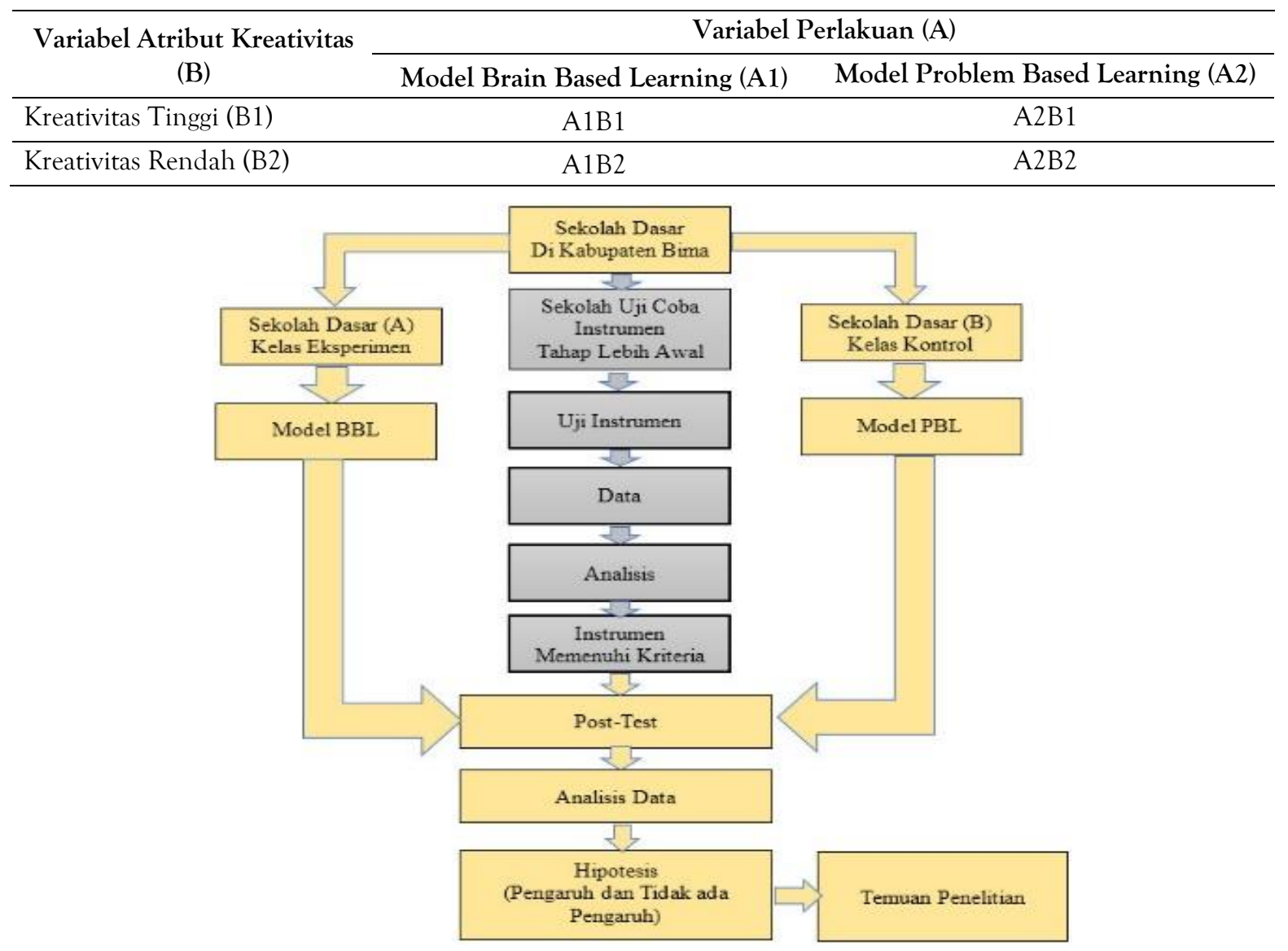

Gambar 3. Diagram Alir Penelitian

Populasi yang dilakukan penelitian ini yaitu pada beberapa siswa Sekolah Dasar yang ada di Kabupaten Bima, dengan teknik pengambilan sampel secara simple random sampling yaitu dengan melakukan memilih sekolah secara acak, menentukan kelas eksperimen dan kelas kontrol, dan pemilihan sekolah berdasarkan kualifikasi akreditas sekolah terakreditasi. 
Jenis instrumen yang digunakan untuk mengukur kreativitas siswa seperti tampak pada gambar 1, sedangkan tes keterampilan berpikir kompleks dilakukan pada pembelajaran matematika dengan menggunakan soal essay yang sudah divalidasi oleh beberapa para ahli instrument yang ada di dosen STKIP Taman Siswa Bima. Pengujian validitas dan reliabilitas tes kreativitas dan keterampilan berpikir kompleks menggunakan korelasi product moment dan alpha cronbach (K.Brahim et al., 2015). Sedangkan pada teknik analisis data dilakukan dengan menguji normalitas, uji homogenitas melalui uji liliefors dan uji F (Pramesti, 2017).

\section{Hasil dan Pembahasan}

\section{Deskripsi Data}

Subjek penelitian dari SDN Nggembe sebagai kelompok Sekolah Eksperimen dan SDN Rada sebagai kelompok Sekolah kontrol. Sampel penelitian diambil sama-sama kelas tinggi yang memiliki tingkat pengukuran kreativitas yang sama. Adapun sampel dapat dilihat pada tabel 2.

Tabel 2. Sampel Penelitian Siswa

\begin{tabular}{lcc}
\hline \multirow{2}{*}{\begin{tabular}{c} 
Variabel Atribut Kreativitas \\
\cline { 2 - 3 }
\end{tabular}} & \multicolumn{2}{c}{ Variabel Perlakuan (A) } \\
\hline Kreativitas Tinggi (B1) & 22 & 22 \\
\hline Kreativitas Rendah (B2) & 22 & 22 \\
\hline
\end{tabular}

Tabel 3. Statistika Deskripsi Data Hasil Keterampian Berpikir Kompleks Matematis

\begin{tabular}{|c|c|c|c|c|c|c|c|c|c|c|}
\hline \multirow{3}{*}{ Kreativitas } & \multicolumn{10}{|c|}{ Perlakuan } \\
\hline & \multicolumn{5}{|c|}{ Model Brain Based Learnig } & \multicolumn{5}{|c|}{ Model Problem Based Learning } \\
\hline & $\mathbf{N}$ & Min & Max & Rata-Rata & SD & $\mathbf{N}$ & Min & Max & Rata-Rata & SD \\
\hline Tinggi & 22 & 63 & 92 & 76,27 & 8,58 & 22 & 42 & 79 & 60,66 & 10,94 \\
\hline Rendah & 22 & 42 & 69 & 62,28 & 9,23 & 22 & 50 & 75 & 59,14 & 6,55 \\
\hline Jumlah & 44 & 42 & 92 & 68,47 & 11,12 & 44 & 42 & 79 & 61 & 8,95 \\
\hline
\end{tabular}

Hasil tabel 3 menunjukkan analisis nilai keterampilan berpikir kompleks matematis bahwa pada model Brain Based Learning dengan kreativitas tinggi mendapatkan nilai rata-rata 76,27 lebih tinggi dibandingkan dengan model Problem Based Learning dengan kreativitas tinggi mendapatkan nilai rata-rata 60,66. Sedangkan pada model Brain Based Learning dengan kreativitas rendah mendapatkan nilai rata-rata 62,28 lebih tinggi dibandingkan model Problem Based Learning dengan kreativitas rendah mendapatkan nilai rata-rata 59.14. Kesimpulan dari data hasil keterampilan berpikir kompleks matematis menujukkan bahwa penerapan model Brain Based Learning lebih baik nilai rata-rata dibandingkan dengan model Problem Based Learning yang semuanya ditinjau dari kreativitas siswa.

\section{Pengujian Prasyarat Analisis}

\section{Uji Normalitas dan Homogenitas Kelompok Siswa Model Brain Based Learning dan Problem Based Learning}

Hasil uji normalitas didapatkan dalam penelitian menunjukkan bahwa nilai signifikansi data hasil keterampilan berpikir kompleks matematis pada model Brain Based Learning sebesar 0,502 > 0,05 hal tersebut menujukkan bahwa nilai keterampilan berpikir kompleks matematis dari 44 sampel berdistribus normal. Kemudian nilai signifikansi dari keterampilan berpikir kompleks matematis dengan menggunakan model Problem Based Learning sebesar 0,096 > 0,05 hal tersebut menunjukkan bahwa nilai keterampilan berpikior kompleks matematis dari 44 sample berdistribusi normal.

Kemudian, hasil uji homogenitas keterampilan berpikir kompleks matematis dari sebanyak 44 sampel penelitian dengan menggunakan model brain based learnig dan model Problem Based Learning memenuhi nilai signifikansi 0,0288>0,05 hal tersebut menunjukkan bahwa data nilai keterampilan berpikir kompleks matemtis siswa memiliki nilai varians yang homogen.

Uji Normalitas dan Homogenitas Kelompok Siswa Perlakuan Model Brain Based Learnig dengan Kreativitas Tinggi dan Model Problem Based Learnig dengan Kreativitas Tinggi 
Hasil uji normalitas didapatkan dalam penelitian menunjukkan bahwa nilai signifikansi data hasil keterampilan berpikir kompleks matematis pada model Brain Based Learning dengan kreativitas tinggi sebesar 0,341 > 0,05 hal tersebut menujukkan bahwa nilai keterampilan berpikir kompleks matematis dari 22 sampel berdistribus normal. Kemudian nilai signifikansi dari keterampilan berpikir kompleks matematis dengan menggunakan model Problem Based Learning dengan kreativitas tinggi sebesar 0,181>0,05 hal tersebut menunjukkan bahwa nilai keterampilan berpikior kompleks matematis dari 22 sample berdistribusi normal.

Kemudian, hasil uji homogenitas keterampilan berpikir kompleks matematis dari sebanyak 22 sampel penelitian dengan menggunakan model brain based learnig dan model Problem Based Learning dengan sama-sama memiliki nilai kreativitas tinggi memenuhi nilai signifikansi $0,181>0,05$ hal tersebut menunjukkan bahwa data nilai keterampilan berpikir kompleks matemtis siswa memiliki nilai varians yang homogen.

\section{Uji Normalitas dan Homogenitas Kelompok Siswa Perlakuan Model Brain Based Learnig dengan Kreativitas Rendah dan Model Problem Based Learnig dengan Kreativitas Rendah}

Hasil uji normalitas didapatkan dalam penelitian menunjukkan bahwa nilai signifikansi data hasil keterampilan berpikir kompleks matematis pada model Brain Based Learning dengan kreativitas rendah sebesar 0,449> 0,05 hal tersebut menujukkan bahwa nilai keterampilan berpikir kompleks matematis dari 22 sampel berdistribus normal. Kemudian nilai signifikansi dari keterampilan berpikir kompleks matematis dengan menggunakan model Problem Based Learning dengan kreativitas rendah sebesar 0,144>0,05 hal tersebut menunjukkan bahwa nilai keterampilan berpikior kompleks matematis dari 22 sample berdistribusi normal.

Kemudian, hasil uji homogenitas keterampilan berpikir kompleks matematis dari sebanyak 22 sampel penelitian dengan menggunakan model brain based learnig dan model Problem Based Learning dengan sama-sama memiliki nilai kreativitas rendah memenuhi nilai signifikansi $0,366>0,05$ hal tersebut menunjukkan bahwa data nilai keterampilan berpikir kompleks matemtis siswa memiliki nilai varians yang homogen.

\section{Pengujian Hipotesis}

\section{Perbedaan Keterampilan Berpikir Kompleks Matematis yang diberikan perlakukan dengan Model Brain Based Learning dan Model Problem Based Learning}

Hasil analisis dengan anava dua arah menunjukkan bahwa siswa yang diberi perlakuan dengan menggunakan model Brain Based Learning memperoleh nilai Fhitung sebesar 25,625, dengan taraf signifikansi 0,05 dan df1 $=1$ dan df2 $=2$, maka nilai Ftabel = 4,3512. Dengan demikian disimpulkan bahwa Fhitung 25,625 $>$ Ftabel 4,3512 sehingga terjadi penolakan HO artinya ada perbedaan nilai keterampilan berpikir kompleks matematis dari kedua model pembelajaran yang berbeda. Selanjutnya adanya penerimaan H1 artinya nilai keterampilan berpikir kompleks matematis yang diberikan perlakuan model Brain Based Learning lebih tinggi dibandingkan dengan perlakuan model Problem Based Learning.

\section{Interaksi antara Pembelajaran yang diberikan dengan Kreativitas Siswa Terhadap Keterampilan Berpikir Kompleks Matematis}

Terdapat interaksi antara kedua model pembelajaran dengan kreativitas siswa terhadap nilai keterampilan berpikir kompleks matematis, hal tersbut dibuktikan dengan nilai signifikansi $0,003<0,05$ dengan taraf signifikansi 0,05. Dari data tersebut menunjukkan terdapat interaksi yang signifikansi antara model pembelajaan yang ditinjauan dari kreativitas siswa terhadap nilai keterampilan berpikir kompleks matematis. Hasil interaksipun menunjukkan bahwa terdapat adanya hubungan model pembelajaran dan kreativitas tidak membentuk garis sejajara artinya garis menyilang. Hal tersebut membuktikan bahwa model Brain Based Learning dalam meningkatkan keterampilan berpikir kompleks matematis lebih cocok dibandingkan model Problem Based Learning.

Perbedaan Keterampilan Berpikir Kompleks Matematis antara Siswa yang Diberikan Model Brain Based Lerarning dengan yang Diberikan Model Problem Based Learning Pada Kelompok Siswa dengan Kreativitas Tinggi

Hasil analisis dengan uji-t menunjukkan bahwa siswa yang diberikan perlakuan model Brain Based Learning dengan kreativitas tinggi memperoleh nilai thitung sevesar 5,274 dengan taraf signifikansi 0,05 dan derajat kebebasan 42, kemudian untuk ttabel 2,018. Sehingga dapat disimpulkan nilai thitung 5,274 > nilai ttabel 2,018 
menunjukkan terjadi penolakan $\mathrm{H} 0$ yang berarti ada perbedaan nilai keterampilan berpikir kompleks matematis antara siswa yang diberi perilakuan kedua model pembelajaran dengan kreativitas tinggi. Selain itu adanya penerimaan $\mathrm{H} 1$ berarti nilai keterampilan berpikir kompleks matematis siswa yang diberi perilakuan model Brain Based Learning lebih tinggi dibandingkan dengan model Problem Based Learning yang sama-sama ditinjau dari kreativitas tinggi.

\section{Perbedaan Keterampilan Berpikir Kompleks Matematis antara Siswa yang Diberikan Model Brain Based Lerarning dengan yang Diberikan Model Problem Based Learning Pada Kelompok Siswa dengan Kreativitas Rendah}

Hasil analisis dengan uji-t menunjukkan bahwa siswa yang diberikan perlakuan model Brain Based Learning dengan kreativitas tinggi memperoleh nilai thitung sevesar 1,544 dengan taraf signifikansi 0,05 dan derajat kebebasan 42, kemudian untuk ttabel 2,018. Sehingga dapat disimpulkan nilai thitung 1,544> nilai ttabel 2,018 menunjukkan terjadi penerimaan $\mathrm{HO}$ yang berarti ada perbedaan nilai keterampilan berpikir kompleks matematis antara siswa yang diberi perilakuan kedua model pembelajaran dengan kreativitas tinggi. Selain itu adanya penerimaan $\mathrm{H} 1$ berarti nilai keterampilan berpikir kompleks matematis siswa yang diberi perilakuan model Brain Based Learning tidak ada perbedaan dengan model Problem Based Learning yang sama-sama ditinjau dari kreativitas rendah

\section{Pembahasan}

Pada hipotesis pertama, kedua, ketiga dan keempat mengikuti taraf signifikan $\alpha=0,05$, hasil penelitian diatas dapat dibahas dengan kajian sebagai berikut:

\section{Perbedaan Keterampilan berpikir kompleks matematis antara Siswa yang diberi Model Brain Based Learning dengan Siswa yang diberi Model Problem Based Learning}

Pada pengujian hipotesis yang pertama telah dibuktikan bahwa terdapat perbedaan antara keterampilan berpikir kompleks matematis siswa yang diberi Model Brain Based Learning dengan siswa yang diberi Model Problem Based Learning. Hasil analisis secara deskriptif maupun dengan menggunakan uji-t menunjukan bahwa ada perbedaan yang signifikan dari nilai keterampilan berpikir kompleks matematis antara kelompok siswa yang diberi Model Brain Based Learning dengan kelompok siswa yang diberikan Model Problem Based Learning . Bahkan, berdasarkan pengolahan data dan uji analisis, siswa yang diberikan Model Brain Based Learning cenderung memiliki keterampilan berpikir kompleks matematis yang lebih tinggi dibandingkan siswa dengan Model Problem Based Learning.

Penerapan Model Brain Based Learning tersebut, dapat dilihat bahwa pembelajaran tersebut memang sangat mendukung peningkatan keterampilan berpikir kompleks matematis siswa. Setiap sintaks yang termuat dalam Model Brain Based Learning mendukung peningkatan keterampilan berpikir kompleks matematis siswa. Hal ini sejalan dengan penelitian yang dilakukan oleh Adiansha et al., (2020) model Brain Based Learning memiliki peranan sangat penting terhadap peningkatan keterampilan berpikir kompleks matematis siswa. Penelitian lain yang memiliki hasil sejalan adalah penelitian oleh Putri et al. (2019) dimana diperoleh bahwa keterampilan berpikir kompleks matematis siswa yang diberikan Model Brain Based Learning lebih tinggi dari siswa yang diberikan pembelajaran langsung. Hasil analisis juga sejalan dengan penelitian yang dilakukan oleh Adiansha \& Sumantri (2017) yang menunjukan bahwa terdapat peningkatan kemampuan komunikasi pada Model Brain Based Learning bernuansa pendidikan karakter dibanding dengan Model Problem Based Learning .

Dengan melihat hasil analisis dan pembahasan diatas, dapat disimpulkan bahwa Model Brain Based Learning berperan sangat penting dan mendukung peningkatan keterampilan berpikir kompleks matematis siswa. Dengan kata lain Model Brain Based Learning memberikan pengaruh positif terhadap peningkatan keterampilan berpikir kompleks matematis jika dibandingkan dengan Model Problem Based Learning .

\section{Adanya Interaksi antara Pembelajaran yang diberikan dengan Tingkat Kreativitas Siswa Terhadap Keterampilan berpikir kompleks matematis Siswa}

Hasil analisis data menunjukan adanya interaksi antara pembelajaran yang digunakan dengan Kreativitas dalam mempengaruhi keterampilan berpikir kompleks matematis siswa. Dengan demikian berarti bahwa 
pembelajaran yang diterapkan di kelas dan kreativitas siswa secara bersama-sama memberikan pengaruh yang signifikan terhadap keterampilan berpikir kompleks matematis siswa.

Interaksi yang ditunjukan hasil penelitian berarti bahwa dalam penerapannya, Model Brain Based Learning dan juga Model Problem Based Learning bergantung pada tingkat kreativitas yang dimiliki siswa. Model Brain Based Learning diduga memiliki pengaruh yang lebih baik dibandingkan Model Problem Based Learning jika ditinjau dari kreativitas siswa. Melalui interaksi dapat diketahui kelompok dengan pembelajaran yang mana yang memiliki nilai rata-rata keterampilan berpikir kompleks matematis yang lebih tinggi. Dalam hal ini kelompok siswa dengan Model Brain Based Learning memiliki nilai rata-rata keterampilan berpikir kompleks matematis yang lebih tinggi.

Lain halnya dengan Model Problem Based Learning dimana siswa kurang berperan aktif dalam pembelajaran, maka keterampilan berpikir kompleks matematisnya pun sulit untuk meningkat. Proses pembelajaran yang kurang melibatkan siswa untuk memahami materi dengan caranya sendiri dan hanya menerima saja penjelasan dari guru, kurang sesuai untuk mengembangkan keterampilan berpikir kompleks matematis. Akan tetapi untuk beberapa siswa dengan tingkat kreativitas tertentu mungkin kondisi belajar yang pasif serta mengikuti apa yang disampaikan guru, akan lebih mudah diikuti dibandingkan ketika harus memahami sendiri materi melalui membaca dan merangkum. Hal inilah yang menyebabkan interaksi antara pembelajaran dengan kreativitas siswa lebih terlihat signifikan.

\section{Perbedaan Keterampilan Berpikir Kompleks Matematis antara Siswa yang diberikan Model Brain Based Learning dengan yang diberikan Model Problem Based Learning Pada Kelompok Siswa Dengan Kreativitas Tinggi}

Pada pengujian hipotesis ketiga Ho ditolak sehingga berarti ada perbedaan yang signifikan antara Model Brain Based Learning dengan Model Problem Based Learning pada kelompok siswa yang memiliki kreativitas tinggi. Hasil analisis statistik deskriptif maupun uji-t memperlihatkan bahwa ada perbedaan antara keterampilan berpikir kompleks matematis siswa yang diberi Model Brain Based Learning dengan Model Problem Based Learning ditinjau dari siswa yang memiliki Kreativitas Tinggi. Selain itu penerimaan Hi berarti bahwa keterampilan berpikir kompleks matematis siswa Kreativitas tinggi dengan Model Brain Based Learning lebih tinggi dibandingkan dengan keterampilan berpikir kompleks matematis siswa Kreativitas Tinggi yang diberi Model Problem Based Learning .

Berdasarkan uraian di atas serta hasil statistik deskriptif dan uji analisis maka dapat diambil kesimpulan bahwa keterampilan berpikir kompleks matematis siswa dengan kreativitas tinggi yang diberikan Model Brain Based Learning akan lebih tinggi dibandingkan dengan siswa dengan kreativitas tinggi yang diberikan Model Problem Based Learning. Dengan kata lain, siswa yang memiliki kreativitas tinggi dapat mencapai hasil lebih baik jika diberikan Model Brain Based Learning dibandingkan jika diberikan Model Problem Based Learning .

Perbedaan Keterampilan Berpikir Kompleks Matematis antara Siswa yang diberikan Model Brain Based Learning dengan yang diberikan Model Problem Based Learning Pada Kelompok Siswa dengan Kreativitas Rendah

Pengujian hipotesis keempat memperlihatkan bahwa Ho diterima yang berarti tidak ada perbedaan yang signifikan antara Model Brain Based Learning dengan Model Problem Based Learning pada kelompok siswa yang memiliki Kreativitas Rendah. Hasil analisis statistik deskriptif maupun uji-t memperlihatkan bahwa tidak ada perbedaan antara keterampilan berpikir kompleks matematis siswa yang diberi Model Brain Based Learning dengan Model Problem Based Learning ditinjau dari siswa yang memiliki Kreativitas Rendah. Selain itu dapat diartikan pula bahwa keterampilan berpikir kompleks matematis siswa yang memiliki Kreativitas rendah dengan Model Brain Based Learning dapat lebih tinggi dibandingkan dengan keterampilan berpikir kompleks matematis siswa dengan kreativitas rendah yang diberi Model Problem Based Learning.

Berdasarkan penjelasan di atas disertai hasil statistik deskriptif dan uji-t, dapat disimpulkan bahwa pembelajaran yang diberikan oleh guru tidak memberikan pengaruh yang signifikan terhadap kemampuan siswa yang memiliki kreativitas rendah. Keterampilan berpikir kompleks matematis siswa pada dua kelompok dengan pembelajaran berbeda tidak berbeda secara signifikan jika ditinjau dari kreativitas yang rendah. 


\section{Simpulan}

Hasil penelitian dan pembahasan dalam penelitian ini menunjukkan bahwa untu hiipotesis pertama mengatakan bahwa terdapat perbedaan keterampilan berpikir kompleks matematis antara siswa yang diberi model Brain Based Learning dengan siswa yang diberi model Problem Based Learning sehingga model Brain Based Learning berperan sangat penting dan mendukung peningkatan keterampilan berpikir kompleks matematis siswa. Dengan kata lain model Brain Based Learning memberikan pengaruh positif terhadap peningkatan keterampilan berpikir kompleks matematis jika dibandingkan dengan model Problem Based Learning. Hipotess kedua mengatakan adanya interaksi antara pembelajaran yang diberikan dengan tingkat kreativitas siswa terhadap keterampilan berpikir kompleks matematis siswa sehingga pembelajaran yang diterapkan di kelas dan kreativitas siswa secara bersama-sama memberikan pengaruh yang signifikan terhadap keterampilan berpikir kompleks matematis siswa. Hipotesis ketiga mengatakan bahwa adanya perbedaan keterampilan berpikir kompleks matematis antara siswa yang diberikan model Brain Based Learning dengan yang diberikan model Problem Based Learning pada kelompok siswa dengan kreativitas tinggi sehingga keterampilan berpikir kompleks matematis siswa dengan kreativitas tinggi yang diberikan model Brain Based Learning akan lebih tinggi dibandingkan dengan siswa dengan kreativitas tinggi yang diberikan model Problem Based Learning . dengan kata lain, siswa yang memiliki kreativitas tinggi dapat mencapai hasil lebih baik jika diberikan model Brain Based Learning dibandingkan jika diberikan model Problem Based Learning. Hipotesis keempat perbedaan keterampilan berpikir kompleks matematis antara siswa yang diberikan model Brain Based Learning dengan yang diberikan model Problem Based Learning pada kelompok siswa dengan kreativitas rendah sehingga pembelajaran yang diberikan oleh guru tidak memberikan pengaruh yang signifikan terhadap kemampuan siswa yang memiliki kreativitas rendah. Keterampilan berpikir kompleks matematis siswa pada dua kelompok dengan pembelajaran berbeda tidak berbeda secara signifikan jika ditinjau dari kreativitas yang rendah.

\section{Ucapan Terima Kasih}

Hasil penelitian dengan judul pengaruh model Brain Based Learning dan Problem Based Learning terhadap keterampilan berpikir kompleks matematis ditinjau dari kreativitas siswa sekolah dasar di Kabupaten Bima mendaparkan dukungan penuh dari Kemenristekbrin dengan melalui hidah penelitian dosen pemula pada penganggaran 2021.

\section{Daftar Pustaka}

Adiansha, A. A., Khatimah, H., \& Asriyadin. (2020). Pengembangan Kreativitas Dalam Pembelajaran Matematika Melalui Model Brain Based Learning Siswa Sekolah Dasar. JURNAL PENDIDIKAN MIPA, 10(1), 45-52. https://doi.org/10.37630/jpm.v10i1.327

Adiansha, A. A., \& Sumantri, M. S. (2017). The Effect of Brain Based Learning Model and Creative Thinking on the Ability of Mathematics Concept of Elementary Students. 5(12), 1195-1199. https://doi.org/10.12691/education-5-12-4

Adiansha, A. A., Sumantri, M. S., \& Makmuri, M. (2018). Pengaruh model Brain Based Learning terhadap kemampuan komunikasi matematis siswa ditinjau dari kreativitas. Premiere Educandum : Jurnal Pendidikan Dasar Dan Pembelajaran, 8(2), 127. https://doi.org/10.25273/pe.v8i2.2905

Anita, D., \& Mumpuniart. (2018). Perangkat Pembelajaran Berbasis Problem Based Learning untuk Meningkatkan Kemampuan Berpikir Kreatif di Sekolah Dasar. Jurnal Pembangunan Pendidikan: Fondasi Dan Aplikasi, 6(2), 132-140. https://doi.org/https://doi.org/10.21831/jppfa.v6i2.23632

Dewi, N., \& Riandi, R. (2016). Analisis Kemampuan Berpikir Kompleks Siswa Melalui Pembelajaran Berbasis Masalah Berbantuan Mind Mapping. Edusains, 8(1), 98-107. https://doi.org/10.15408/es.v8i1.1805

Haynes, B. (2020). Can creativity be taught? Educational Philosophy and Theory, 52(1), 34-44. https://doi.org/10.1080/00131857.2019.1594194 
K.Brahim, T., Abdullah, K., \& Hasan, N. (2015). Penelitian Ilmiah (Pengertian, Penerapan, dan Pengetahuan Tambahan). Suara GKYE Peduli Bangsa.

Maskur, R., Sumarno, Rahmawati, Y., Pradana, K., Syazali, M., Septian, A., \& Palupi, E. K. (2020). The effectiveness of Problem Based Learning and aptitude treatment interaction in improving mathematical creative thinking skills on curriculum 2013. European Journal of Educational Research, 9(1), 375-383. https://doi.org/10.12973/eu-jer.9.1.375

OECD. (2019). PISA 2018 Results. Combined Executive Summaries VOLUME I, II \& III. Journal of Chemical Information and Modeling, 53(9), 1689-1699.

Permana, R., \& Adiansha, A. A. (2019). Membentuk Keterampilan Berpikir Kritis Matematis Siswa Melalui Model Brain Based Learning Ditinjau Dari Penalaran Induktif. JURNAL PENDIDIKAN MIPA, 9(1 SE-Articles). https://doi.org/10.37630/jpm.v9i1.177

Pllana, D. (2019). Creativity in Modern Education. World Journal of Education, 9(2), 136. https://doi.org/10.5430/wje.v9n2p136

Pramesti, G. (2017). Statistika Penelitian dengan SPSS 24. PT Elex Media Komputindo.

Schleicher, A. (2019). PISA 2018 Insights and Interpretations. Japanese Journal of Anesthesiology, 24(1), $12-17$.

Sunardjo, R. N., Yudhianto, S. A., \& Rahman, T. (2016). Analisis Implementasi Keterampilan Berpikir Dasar dan Kompleks dalam Buku IPA Pegangan Siswa SMP Kurikulum 2013 dan Implementasinya dalam Pembelajaran. Proceeding Biology Education Conference, 13(1), 133-144.

Yasar, D. M. (2017). Brain Based Learning in Science Education in Turkey: Descriptive Content and Meta Analysis of Dissertations. Journal of Education and Practice, 8(9), 161-168. 